\title{
PENGARUH WAKTU HIDROLISIS TERHADAP KARAKTERISTIK HIDROLISAT PROTEIN IKAN TOMAN (Channa micropeltes) ASAL DAS KALIMANTAN TIMUR
}

\section{EFFECTS OF HYDROLISYS TIME ON CHARACTERISTIC OF HYDROLYSAT PROTEIN OF TOMAN FISH (Channa micropeltes) FROM MAHAKAM RIVER, EAST KALIMANTAN}

\author{
Arba Susanty ${ }^{1}$, Indrati Kusumaningrum ${ }^{2}$ \\ 1) Balai Riset dan Standardisasi Industri Samarinda. \\ Jalan MT. Haryono/ Banggeris No.1, Samarinda, \\ 2) Fakultas Perikanan dan Ilmu Kelautan Universitas Mulawarman Samarinda \\ email: arbasusanty@gmail.com
}

Diterima: $08-11-2021$

Direvisi: $17-12-2021$

Disetujui: 28 -12- 2021

\begin{abstract}
ABSTRAK
Hidrolisat protein merupakan produk yang dihasilkan dari penguraian protein ikan menjadi senyawa-senyawa rantai pendek. Hidrolisat protein ikan, dapat dikembangkan menjadi produk yang mempunyai sifat fungsional yang tinggi. Hidrolisis secara enzimatis dapat menghasilkan penurunan ukuran peptida sehingga dapat merubah karakteristik fungsional protein. Penelitian ini bertujuan untuk mengetahui pengaruh waktu hidrolisis protein ikan toman terhadap karakteristik dan profil asam aminonya. Proses hidrolisat dilakukan secara enzimatis, yaitu menggunakan enzim bromelain dengan perlakuan waktu hidrolisis 3, 4, 5 dan 6 jam. Selanjutnya dianalisis rendemen, derajat hidrolisis dan hasil terbaik dianalisis proksimat dan profil asam aminonya. Hasil penelitian ini menunjukkan hidrolisat protein ikan toman dapat dihasilkan melalui hidrolisis menggunakan enzim bromelain. Rendemen hidrolisat protein ikan toman berkisar 9,14 - 13,25\%. Derajat hidrolisis antara 0,274 - 2,602. Hidrolisat protein ikan toman memiliki karakteristik kadar air 6,93 $\%$, kadar abu 2,01\%, protein 40,74\% dan lemak 0,05\%, karbohidrat $44,6 \%$, kalsium $0,88 \%$, magnesium $0,061 \%$ dan phosphor $0,136 \%$. Waktu hidrolisis berpengaruh terhadap rendemen dan derajat hidrolisis hidrolisat protein ikan toman. Waktu hidrolisis optimum adalah 4 jam dengan rendemen $9,14 \%$ dan derajat hidrolisis 2,602 . Hidrolisat protein ikan toman memiliki asam amino jenis serin, asam glutamate, fenilalanin, isoleusin, valin, arginine, glisin, lisin, asam aspartate, leusin, tirosin, prolin, threonine dan histidine
\end{abstract}

Kata kunci: bromelain, enzim, hidrolisis, Channa micropeltes

\begin{abstract}
Hydrolysate protein is a product that is produced from decomposition of fish protein into short chain compounds. Fish protein hydrolyzate, can be developed into products that have high functional properties. Enzymatic hydrolysis can produce a decrease in peptide size so that it can change the functional characteristics of proteins and improve their quality. This study aims to hydrolyze proteins from all parts of toman fish (Channa micropeltes) except stomach contents. The hydrolyzate process is carried out enzymatically with the treatment of hydrolysis time of 3, 4, 5 and 6 hours. Then characterization of hidrolizate include yield, proximate, and amino acid profile. The results of this study showed that the protein hydrolyzate of toman fish (Channa micropeltes) can be produced by hydrolysis using the enzyme bromelain for 4 hours. The yield of toman hydrolyzate protein (Channa micropeltes) ranged from $5.28-13.25 \%$. The degree of hydrolysis is between 0.274 - 2.602. Toman fish protein hydrolyzate has the characteristics of water content $6.93 \%$, ash content $2.01 \%$, protein $40.74 \%$ and fat $0.05 \%$, carbohydrates $44.6 \%$, calcium $0.88 \%$, magnesium $0.061 \%$ and phosphorus $0.136 . \%$. Hydrolysis time affects the yield and degree of hydrolysis of toman fish protein hydrolyzate. The optimum hydrolysis time was 4 hours with a yield of $9.14 \%$ and a hydrolysis degree of 2.602. Toman fish protein hydrolyzate has amino acids of serine,
\end{abstract}


glutamic acid, phenylalanine, isoleucine, valine, arginine, glycine, lysine, aspartic acid, leucine, tyrosine, proline, threonine and histidine.

Keywords: bromelain, enzyme, hydrolysis, Channa micropeltes

\section{PENDAHULUAN}

Tan toman (Channa micropeltes) merupakan ikan air tawar terbesar dalam famili Channidae. Jenis hewan dalam famili ini adalah hewan karnivora atau - predator. Ikan toman mempunyai kemiripan dengan ikan gabus yang bersifat agresif. Ikan toman dalam habitatnya memangsa ikan-ikan kecil, serangga dan juga kodok (Lekha, 2020). Potensi produksi ikan toman di Kalimantan Timur cukup besar. Data produksi ikan toman di provinsi Kalimantan Timur pada tahun 2018 sebesar 2.321,86 ton (KKP, 2021). Tingkat ketersediaan ikan untuk perikanan darat sebesar 192.680 ton (2019). Dengan produksi perikanan darat sebesar 186.073 ton (2018). Produksi ikan secara keseluruhan sebesar 43.138 ton dan produksi dari karamba sebesar 64.567 ton. Ikan toman dapat diperoleh dari perairan umum dan karamba (DKP Prov. Kaltim, 2019)

Ikan toman segar mempunyai kandungan gizi yang cukup tinggi. Ikan segar merupakan ikan yang baru ditangkap yang mempunyai mutu yang tidak mudah berubah serta tidak mengalami kerusakan. Menurut (Restu, 2012), kandungan gizi ikan toman segar memiliki kadar air 74,1\%, kadar protein 18,92\%, kadar lemak 5,23\% dan kadar abu 0,94\%. Daging ikan toman dimanfaatkan sebagai bahan pembuatan nugget ikan. Pemanfaatan ikan toman di masyarakat pada umumnya sebagai bahan baku kerupuk ikan. Hasil beberapa penelitian pemanfaatan ikan toman sebagai bahan pangan antara lain daging ikan toman sebagai bahan nugget ikan (Restu, 2012), bahan pembuatan serundeng (Alfitri et al., 2015) dan hasil penelitian (Hermanto \& Susanty, 2020) yang menyebutkan penambahan tepung ikan toman pada formulasi biskuit berpengaruh terhadap karakteristik fisikokimia dan sensoris biskuit. Selain sebagai bahan pangan, ekstrak ikan toman dapat pula dipalikasikan pada bidang farmasi dan kosmetika. Beberapa penelitian ekstrak ikan toman antara lain (Firlianty \& Pratasik, 2018) yang melaporkan pemberian pudding dengan ekstrak ikan toman dan ikan gabus (family: Chanidae) dapat mempercepat penyembuhan luka dan meningkatkan berat badan pada hewan uji tikus. Ekstrak ikan toman dapat pula diaplikasikan pada produk hidroksipropil metilselulosa (HPMC) yaitu sebagai sediaan gel untuk produk makanan dan kosmetika, dimana pada konsentrasi penambahan ektrak ikan toman 0,4-5\% memberikan homogenitas yang baik untuk gel HPMC (Firlianty et al., 2019). Protein ikan gabus dan ikan toman cukup tinggi dan banyak mengandung protein albumin yang baik untuk kesehatan. Sedangkan Nurilmala et al., (2020) menyebutkan ekstrak segar ikan gabus memilki kadar protein $11,62 \%$ dan ekstrak rebus terdapat pada ikan toman 8,19\%.

Kandungan protein yang cukup tinggi tersebut sangat berpotensi dijadikan produk hidrolisat protein ikan. Hidrolisat protein ikan merupakan produk yang dihasilkan dari penguraian protein ikan menjadi senyawa-senyawa rantai pendek. Hidrolisis protein dapat memperkecil ukuran protein sehingga merupakan sumber asam amino yang memiliki berbagai sifat fungsional yang baik (Chalamaiah et al., 2012). Hidrolisat protein ikan dihasilkan dari proses penguraian protein ikan menjadi peptida sederhana maupun asam amino melalui proses hidrolisis oleh enzim, asam atau basa. Hidrolisat protein ikan dapat dimanfaatkan sebagai bahan baku untuk penambah citarasa, sumber protein dan asam amino pada bahan pangan. Penelitian - penelitian mengenai hidrolisat protein ikan sudah ada yang melaporkan di antaranya; (Wijayanti et al., 2016), menyebutkan konsentrasi enzim bromelin berpengaruh nyata pada kadar protein, lemak, air dan abu akan tetapi tidak berpengaruh nyata pada kadar karbohidrat hidrolisat protein ikan bandeng. Alfitri et al., 2015 menyebutkan bahwa ikan toman pada umumnya kurang diminati masyarakat karena rasa dagingnya yang hambar. Hal ini mengakibatkan kelebihan produksi ikan 
toman. Salah satu alternatif memanfaatkan ikan toman yaitu dengan diversifikasi produk olahan. Pemanfaatan ikan toman menjadi hidrolisat protein diharapkan dapat meningkatkan nilai tambah (added value). Pemanfaatan hidrolisat protein ikan dapat diaplikasikan pada industri pangan maupun non pangan. Aplikasi produk hidrolisat protein ikan berkaitan dengan sifat fungsional yang dimiliki seperti emulsifier, flavour enhancer, texturizer, stabilizer, foaming agent dan gelling agent. Sifat fisikokimia lainnya yaitu memiliki solubilitas tinggi, kapasitas emulsi dan kapasitas mengikat minyak (He et al., 2013)

Roslan et al., (2014) menyatakan kompsoisi kimia dan asam amino dari hidrolisat protein limbah ikan nila (Oreochromis niloticus) memiliki nilai nutrisi yang tinggi dengan kadar protein $(62,71 \%)$ dan komposisi asam amino esensial $(199,15 \mathrm{mg} / \mathrm{g})$. Hidrolisat protein ini memiliki potensi dalam mengatasi hipertensi karena tingginya aktivitas penghambatan Angiotensin Converting Enzyme (ACE) $(88,26 \%$ ) disebabkan adanya peptida dengan berat molekul dibawah $5 \mathrm{kDa}$. Hidrolisat ikan gabus memiliki potensi antihiperglikemik yaitu daya hambat terhadap enzim $\alpha$-glukosidase sebesar $74 \%$ dengan kandungan asam amino sebesar $51,15 \%$ dan kadar protein $90,43 \%$.

Sifat fungsional hidrolisat protein ikan berkaitan dengan komposisi asam amino hasil pemecahan protein ikan setelah dihdrolisis. Komposisi asam amino hidrolisat protein ikan berperan penting terhadap sifat fungsionalnya (dos Santos et al., 2011). Proses hidrolisis dapat mengubah sifat protein seperti menurunkan memperkecil berat molekul, meningkatkan jumlah gugus terionisasi dan dapat menghasilkan gugus hidrofobik dalam jumlah banyak. Sifat-sifat tersebut sangat penting digunakan dalam formulasi pangan yang mempengaruhi penampakan dan sifat-sifat dalam sistem pangan. Sifat-sifat fisikokimia tersebut sangat penting ketika hidrolisat protein berinteraksi dengan komponen lain dalam pangan seperti minyak dan air (He et al., 2013) Penelitian ini bertujuan untuk mengetahui pengaruh waktu hidrolisis protein iakn toman terhadap karakteristik dan profil asam aminonya.

\section{METODE PENELITIAN}

Bahan utama yang digunakan adalah ikan toman (Channa micropeltes) yang diperoleh dari DAS Mahakam Kecamatan Muara Muntai dan Kotabangun, Kabupaten Kutai Kartanegara, Kalimantan Timur. Enzim komersial berupa bromelain (Xian Lyphar Biotech, RRC). Bahan kimia yang digunakan untuk menganalisis produk hidrolisat adalah $\mathrm{NaOH}$, maltodekstrin, $\mathrm{K}_{2} \mathrm{SO}_{4}, \mathrm{HgO}, \mathrm{H}_{2} \mathrm{SO}_{4}, \mathrm{H}_{3} \mathrm{BO}_{3}$, metilen merah, metilen biru, alkohol, $\mathrm{HCl}$, asam asetat glasial dari merck dan akuades. Semua bahan-bahan reagen kimia yang digunakan dalam analisis kimia adalah bahan kimia dengan grade analitik.

Ikan toman dibersihkan isi perut dan dicuci bersih, kemudian dipotong-potong untuk dilakukan proses pemasakan menggunakan High Pressure Cooking (tekanan $2 \mathrm{~kg} / \mathrm{cm}^{2}$; selama 60 menit). Sampel ikan kemudian dihaluskan dan dikemas dalam plastik Polyethylen dan disimpan dalam freezer hingga menunggu proses selanjutnya. Sampel ikan selanjutnya dihidrolisis dengan enzim bromelain pada variasi waktu hidrolisis 3 jam, 4 jam, 5 jam dan 6 jam, diulang sebanyak 3 kali. Proses berikutnya setelah hidrolisis yaitu pengeringan sampel menggunakan pengering semprot (Spray Drying). Sampel yang telah kering selanjutnya dimasukkan dalam wadah tertutup dan disimpan hingga dilakukan analisis kimia, yaitu meliputi perhitungam rendemen dan rasio nitrogen total terlarut (NTT) dan nitrogen total bahan (NTB) (NTT/NTB). Perhitungan rendemen sebagai berikut:

$$
\text { Rendeman }(\%)=\frac{\text { Bobot hidrolisat protein ikan (akhir) }}{\text { Bobot bahan baku ikan (awal) }} \times 100 \%
$$


Perhitungan rasio NTT/NTB dilakukan untuk menunjukkan derajat hidrolisis (DH). Dilanjutkan dengan pengujian proksimat dan profil asam amino untuk perlakuan dengan nilai DH terbaik. Analisis proksimat meliputi pengujian kadar air, abu, protein dan lemak dengan metode (AOAC, 2005). Pengujian profil asam amino menggunakan High Performance Liquid Chromatography (HPLC). Diagram alir proses hidrolisis dapat dilihat pada gambar 1.

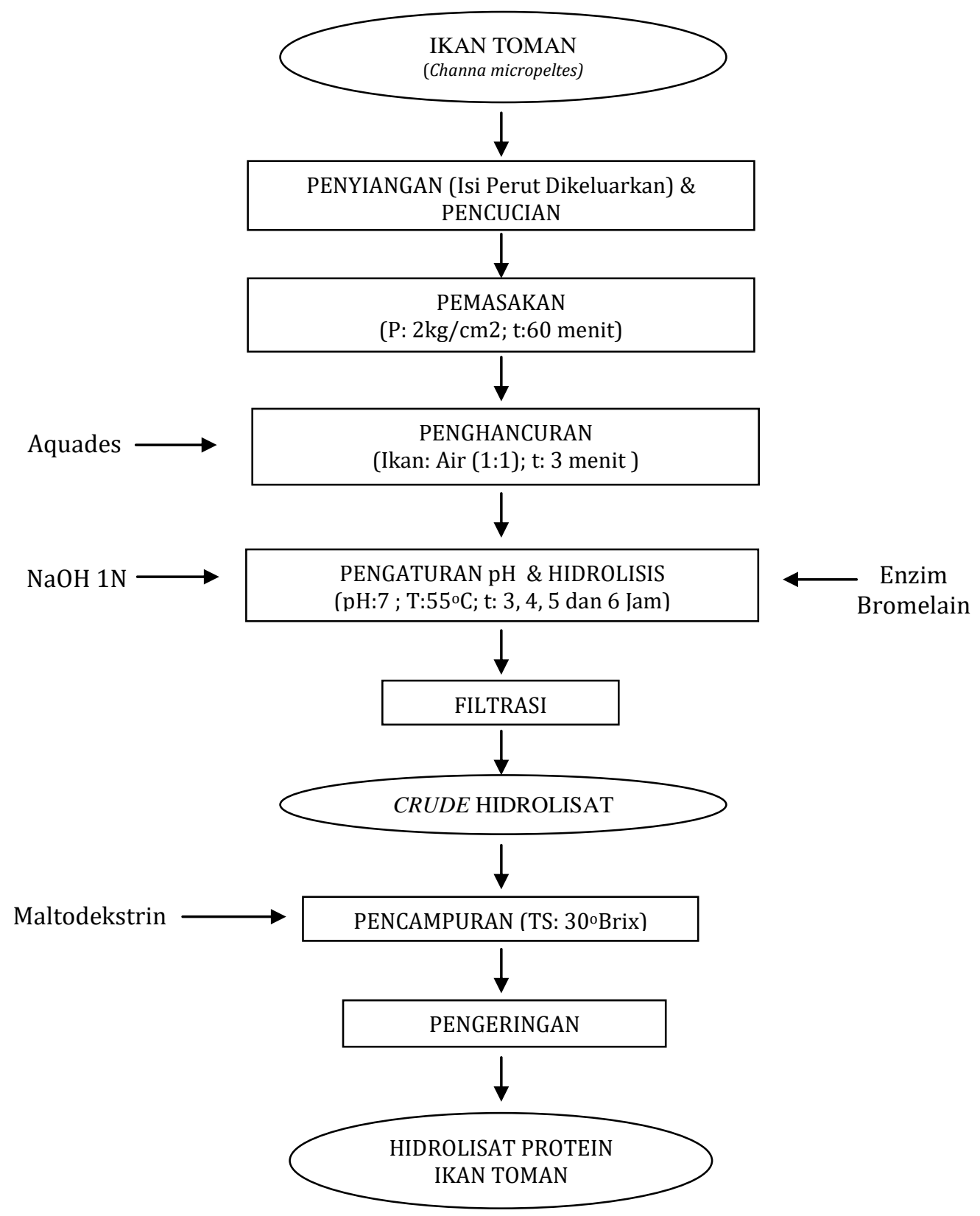

Gambar 1. Diagram Alir Proses Hidrolisis Ikan Toman (Channa micropeltes)

\section{HASIL DAN PEMBAHASAN}

Rendemen dan Derajat Hidrolisis Hidrolisat Protein Ikan Toman

Ikan Toman yang digunakan dalam penelitian ini merupakan hasil tangkapan (ikan toman liar) bukan hasil dari budidaya karamba. Pemilihan ikan toman hasil tangkapan 
disebabkan budidaya ikan toman ini masih terbatas. Menurut (Ansyari \& Slamat, 2020), pengembangan budidaya ikan toman masih terbatas disebabkan tingkat mortalitas pada saat pendederan yang tinggi, sumber benih yang masih harus diambil dari alam dan belum adanya formulasi pakan ikan yang tepat baik untuk pakan benih maupun pakan ikan muda hingga dewasa. Hasil tangkapan ikan toman sebagai bahan baku penelitian ini memiliki rata-rata berat $1.834,96$ gram dengan panjang rata-rata $44,45 \mathrm{~cm}$. Seluruh bagian ikan kecuali isi perut digunakan untuk pembuatan HPIT (hidrolisat protein ikan toman). Setelah proses pelunakkan ikan menggunakan high pressure cooking pada suhu $132^{\circ} \mathrm{C}$, tekanan $2 \mathrm{~kg} / \mathrm{cm}^{2}$ selama 60 menit terjadi rata-rata kehilangan berat bahan sebesar $30,87 \%$.

Proses hidrolisis menggunakan enzim, substrat yang digunakan diubah menjadi produk hidrolisat. Rendemen hidrolisat adalah persentase banyaknya produk hidrolisat yang dihasilkan terhadap berat bahan baku sebelum dihidrolisis. Terlarutnya komponen gizi seperti lemak, protein, dan mineral selama proses hidrolisis mempengaruhi besarnya rendemen produk hidrolisat yang dihasilkan (Shahidi et al., 1995). Rendemen produk hidrolisat protein ikan toman dengan waktu hidrolisis yang berbeda disajikan pada Tabel 1.

Tabel 1. Rendemen hidrolisat protein ikan toman

\begin{tabular}{cc}
\hline $\begin{array}{c}\text { Waktu Hidrolisis } \\
(\text { Jam })\end{array}$ & $\begin{array}{c}\text { Rendemen } \\
(\%)\end{array}$ \\
\hline 3 & 9,36 \\
4 & 9,14 \\
5 & 11,02 \\
6 & 13,25 \\
\hline
\end{tabular}

Hasil penelitian menunjukkan adanya peningkatan rendemen hidrolisat seiring dengan penambahan waktu hidrolisis dari 9,14 - 13,25\%. Nilai rendemen menggambarkan nilai ekonomis suatu bahan. Semakin tinggi nilai rendemen, maka semakin tinggi nilai ekonomisnya karena semakin tinggi jumlah yang dapat dimanfaatkan dari bahan tersebut.

Menurut (Piggot \& Tucker, 1990) hidrolisis protein melibatkan penambahan air sehingga jumlah air yang berada dalam proses menjadi lebih besar dibandingkan dengan jumlah substrat yang digunakan. Penambahan akuades dalam proses hidrolisis bertujuan menstabilkan nilai $\mathrm{pH}$ dalam proses hidrolisis protein, mempermudah pengadukkan dan homogenisasi antara enzim dan substrat yang ada serta berpengaruh terhadap laju reaksi enzimatik. Penggunaan air juga mampu memperluas bidang kontak antara enzim dan substrat, sehingga pada rentang waktu tertentu dapat dihasilkan produk hidrolisat yang lebih besar. Pada penelitian ini jumlah perbandingan air dan ikan yang digunakan (1:1). Penggunaan seluruh bagian ikan menghasilkan padatan yang sangat padat karena adanya bagian tulang, sisik maupun daging ikan sendiri, sehingga substrat yang digunakan untuk proses hidrolisis ini juga sangat pekat. Penggunaan seluruh bagian ikan toman ini dilakukan untuk meminimalisir bagian-bagian ikan yang tidak termanfaatkan dengan baik. Tulang dan sisik ikan dapat menjadi sumber mineral pada hidrolisat ikan toman ini. Rasio air dan substrat (1:1) berpengaruh terhadap bidang kontak enzim dan substrat, akan tetapi dengan waktu hidrolisis yang meningkat maka kontak enzim dan substrat semakin meningkat, menghasilkan rendemen hidrolisat yang semakin tinggi seiring dengan bertambahnya waktu hidrolisis. Tabel 1 menunjukkan bahwa pada waktu 6 jam hidrolisat protein ikan toman yang dihasilkan memiliki rendemen yang paling tinggi $13,25 \%$.

Derajat hidrolisis dapat menjadi indikator keberhasilan proses hidrolisis protein. Derajat hidrolisis yang semakin tinggi menunjukkan bahwa proses hidrolisis protein yang 
berlangsung juga semakin baik. Menurut Haslaniza et al., (2010) peningkatan derajat hidrolisis disebabkan oleh peningkatan peptida dan asam amino yang terlarut dalam TCA akibat pemutusan ikatan peptida selama proses hidrolisis protein.

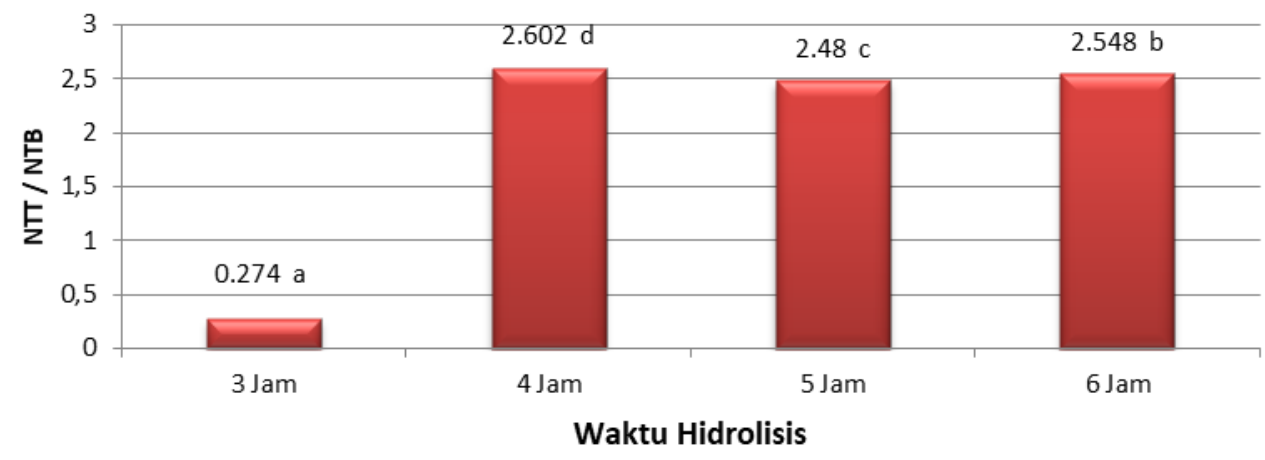

Gambar 2. Rerata NTT/NTB pada waktu hidrolisis yang berbeda

Pada gambar 2 menunjukkan perbandingan nilai nitrogen total terlarut dan nitrogen total bahan (NTT/NTB) yang dapat menunjukkan derajat hidrolisis ikan toman berdasarkan waktu hidrolisis. Hasil analisis sidik ragam menunjukkan waktu hidrolisis berpengaruh nyata terhadap derajat hidrolisis ikan toman. Hasil uji lanjut menunjukkan semua perlakuan waktu hidrolisis berbeda nyata. Pada waktu hidrolisis 4 jam merupakan waktu optimum yang menghasilkan derajat hidrolisis yang tertinggi $(2,602)$. Selama hidrolisis terjadi konversi protein yang bersifat tidak larut menjadi senyawa nitrogen yang bersifat larut, selanjutnya terurai menjadi senyawa-senyawa yang lebih sederhana, seperti peptida-peptida, asam amino dan amonia sehingga mudah diserap oleh tubuh. Shahidi et al., (1995) menyatakan bahwa pada tahap awal proses hidrolisis, enzim akan diserap ke dalam suspensi partikel daging ikan, kemudian didalamnya terjadi pemutusan ikatan peptida yang terjadi secara simultan. Pada waktu tertentu, kecepatan hidrolisis akan mengalami penurunan dan memasuki tahap stasioner. Tahap stasioner terjadi karena adanya penghambatan kinerja enzim untuk menghidrolisis substrat akibat terbentuknya produk dalam jumlah besar. Asam amino yang terbentuk dari proses hidrolisis akan menutup sisi aktif protein substrat, sehingga enzim tidak dapat melanjutkan proses hidrolisis.

Menurut Jamil et al., (2016) perbedaan rendemen dan derajat hidrolisis dari HPI terjadi karena perbedaan dalam spesies ikan, bagian ikan, jenis enzim yang digunakan, dan kondisi hidrolisis yang diterapkan. Kondisi hidrolisis pada penelitian ini adalah pengaruh waktu hidrolisis. Pada kondisi waktu hidrolisis optimum 4 jam menghasilkan rendemen 9,14 dan derajat hidrolisis 2,602. Rendemen yang dihasilkan pada penelitian ini lebih rendah dibandingkan dengan penelitian HPI ikan bandeng pada kondisi hidrolisis 6 jam dengan enzim bromelain yaitu 11,41\% (Wijayanti et al., 2016) dan HPI daging ikan lele dumbo yang dihidrolisis dengan enzim papain pada waktu hidrolisis 6 jam yang menghasilkan rendemen 21,16\% (Salamah et al., 2012). Masih rendahnya rendemen hidrolisat protein ikan toman dibanding dengan jenis ikan lainnya dapat disebabkan oleh rasio penambahan air yang hanya (1:1), jenis enzim yang digunakan serta waktu optimum hidrolisis. Seperti dijelaskan oleh Wijayanti et al., (2016), bahwa hidrolisis protein melibatkan pemberian air sehingga jumlah air yang berada dalam proses menjadi lebih besar dibandingkan dengan jumlah substrat yang digunakan. Terlarutnya berbagai komponen gizi seperti protein, lemak dan mineral selama proses hidrolisis berpengaruh terhadap besarnya rendemen produk hidrolisat yang dihasilkan.

Proses pengeringan menggunakan alat spray dryer dan suhu pengeringan juga berpengaruh terhadap rendemen hidrolisat protein ikan toman. Hariyadi (2017) 
menyebutkan kondisi pengeringan yang sangat berpengaruh pada spray dryer antara lain adalah perbedaan antara suhu inlet dan suhu outlet, kecepatan aspirator, kecepatan penyemprotan, konsentrasi bahan dan kecepatan pompa.

Pada penelitian ini suhu pengeringan pada alat spray dryrer adalah suhu inlet $100^{\circ} \mathrm{C}$ dan suhu outlet $80^{\circ} \mathrm{C}$. Penggunaan suhu yang tidak terlalu tinggi ini dapat menyebabkan rendemen yang dihasilkan masih dibawah hidrolisat protein ikan lainnya. Penggunaan suhu tersebut disesuaikan dengan kemampuan alat yang dimiliki dan untuk menghindari kerusakan bahan yang akan dikeringkan. Menurut Dewi \& Satibi, (2009) peningkatan suhu pengeringan pada spray dryer menyebabkan kadar air pada produk akan semakin menurun. Hal ini karena suhu pengeringan berperan dalam penguapan air yang terkandung dalam bahan. Semakin tinggi suhu pengeringan maka semakin banyak air yang dapat diuapkan sehingga kandungan air produk semakin kecil. Suhu spray dryer yang semakin tinggi, rendemen bubuk ekstrak yang dihasilkan juga semakin tinggi. Suhu spray dryer yang lebih tinggi akan menghasilkan bubuk yang lebih kering, produk yang menempel pada tabung lebih sedikit, serta kehilangan produk yang lebih kecil.

Selain itu penambahan maltodextrin pada hidrolisat protein ikan toman sebagai bahan pengisi dan pelindung komponen penting pada hidrolisat protein, dapat berperan meningkatkan rendemen hidrolisat protein ikan toman yang dihasilkan. Maltodextrin berfungsi untuk melindungi komponen dan senyawa penting dalam bahan seperti antioksidan dan asam amino. Hal ini karena maltodextrin memiliki daya ikat yang kuat terhadap bahan-bahan yang disalut (Maziyatul et al., 2019). Menurut Kembaren et al., (2014) maltodekstrin sangat banyak aplikasinya seperti sebagai bahan pengental, emulsifier dan bahan pengisi. Bahan pengisi perlu ditambahkan pada bahan yang akan dikeringkan dengan proses spray drying untuk menghilangkan kecenderungan bubuk menempel di dinding pengering pada alat spray dryer.

\section{Komposisi Kimia}

Komposisi kimia pangan sangat penting tidak hanya untuk nutrisi kesehatan manusia, akan tetapi juga bagi pengembangan potensi dan aplikasi bahan-bahan pangan pada sistem pangan. Komposisi kimia hidrolisat protein ikan toman dengan waktu yang berbeda disajikan pada Tabel 2.

Tabel 2. Komposisi kimia hidrolisat protein ikan toman pada waktu hidrolisis 4 jam dan suhu $70^{\circ} \mathrm{C}$.

\begin{tabular}{lc}
\hline \multicolumn{1}{c}{ Parameter } & Hidrolisat Protein Ikan Toman \\
\hline Kadar Air & $6,93 \%$ \\
Kadar Abu & $2,01 \%$ \\
Protein & $40,74 \%$ \\
Lemak & $0,05 \%$ \\
Karbohidrat & $44,6 \%$ \\
Kalsium (Ca) & $0,88 \%$ \\
Magnesium $(\mathrm{Mg})$ & $0,061 \%$ \\
Phospor (P) & $0,136 \%$ \\
\hline
\end{tabular}

\section{Kadar Air}

Air berperan sebagai tempat terjadinya reaksi kimia dan merupakan pereaksi utama dalam reaksi hidrolisis (Belitz et al., 2009). Kadar air yang terkandung dalam hidrolisat protein ikan toman lebih tinggi (6,93\%) dibandingkan kadar air ikan lele dumbo $(5,46 \%)$ dan kadar air pada hidrolisat protein ikan komersial $(5,00 \%)$. Struktur bahan 
pangan akan mengalami perubahan akibat proses pengeringan. Sebagian besar air akan menguap ketika mengalami kontak dengan panas saat proses pengeringan berlangsung, sehingga kadar air yang terkandung dalam bahan pangan juga akan menurun. Kadar air yang dihasilkan dari proses pengeringan dengan metode spray drying dipengaruhi oleh suhu inlet dan outlet yang digunakan. Hariyadi (2017) menyebutkan semakin besar perbedaan antara suhu inlet dan suhu outlet akan meningkatkan kadar air produk akhir dan semakin tinggi kecepatan aspirator semakin rendah waktu tinggal (residence time) yang akan meningkatkan kadar air produk akhir, semakin tinggi kecepatan aspirator maka tingkat pemisahan produk di siklon semakin tinggi, semakin tinggi kecepatan penyemprotan maka ukuran partikel kering yang dihasilkan akan semakin kecil, semakin tinggi konsentrasi bahan yang disemprotkan maka ukuran partikel yang dihasilkan akan semakin besar, serta semakin tinggi kecepatan pompa maka suhu outlet akan menurun. Suhu inlet pada penelitian ini adalah $100^{\circ} \mathrm{C}$ dan suhu outlet adalah $80^{\circ} \mathrm{C}$. Perbedaan $20^{\circ} \mathrm{C}$ suhu inlet dan outlet ini menghasilkan kadar air hidrolisat protein ikan toman masih lebih tinggi dibandingkan ikan lainnya.

Penambahan maltodekstrin pada penelitian ini untuk meningkatkan rendemen menghasilkan produk yang bersifat porous dan mudah menyerap air. Produk yang dihasilkan dari metode spray drying berupa serbuk yang berwarna cerah dan bersifat porous (Berk, 2009) Pembuatan hidrolisat protein ikan toman dalam bentuk serbuk selain mempermudah proses penyimpanan dan memperpanjang masa simpan produk, memudahkan pula dalam aplikasinya sebagai bahan fortifikasi pangan maupun bahan ingredient.

\section{Kadar Abu}

Sebagian besar bahan pangan terdiri atas $96 \%$ bahan organik dan air, sisanya terdiri atas unsur-unsur mineral. Proses pembakaran bahan pangan sampai suhu $600^{\circ} \mathrm{C}$ akan menyebabkan bahan organik terbakar, namun bahan anorganik tidak terbakar, yaitu dalam bentuk abu yang terdiri atas berbagai unsur mineral yaitu $\mathrm{Ca}, \mathrm{Mg}, \mathrm{Na}, \mathrm{P}, \mathrm{K}, \mathrm{Fe}, \mathrm{Mn}$ dan $\mathrm{Cu}$. (Sulistyoningsih et al., 2019) menyebutkan bahwa bahan pangan mengandung senyawa anorganik yaitu mineral atau abu. Dengan sumber mineral yang sangat beragam, maka analisis kadar abu sangat penting dilakukan sehingga kualitas gizi suatu bahan dapat diketahui. Analisis abu juga digunakan sebagai indikator mutu pangan lainnya.

Hasil analisis menunjukkan kadar abu hidrolisat protein ikan toman yaitu 2,01\%. Hasil ini lebih tinggi dibanding kadar abu hidrolisat ikan lele 1,79\% (Salamah et al.,2012) akan tetapi masih dibawah hidrolisat ikan komersial 4-7\%. Pada penelitian ini, bahan yang digunakan adalah seluruh bagian ikan toman termasuk tulang dan sisik kecuali isi perut. Rendahnya kadar abu ini disebabkan masih banyaknya mineral yang terikat pada substrat yang dikeringkan menjadi tepung ikan. Hal ini disebabkan rasio air dan bahan hanya (1:1), sehingga mineral masih banyak terikat pada substrat.

Selain itu penambahan $\mathrm{NaOH}$ dalam proses hidrolisis ikan toman untuk mencapai nilai $\mathrm{pH}$ optimum dan menjaga agar $\mathrm{pH}$ tetap konstan selama proses hidrolisis sehingga pemutusan ikatan peptida oleh enzim dapat tetap berlangsung dan dapat meningkatkan kadar abu. (Samaranayaka \& Li-chan, 2008) menyatakan bahwa pencampuran senyawa asam dan alkali dalam larutan hidrolisat protein akan menyebabkan terbentuknya senyawa garam, sehingga dapat meningkatkan kadar abu pada hidrolisat protein.

\section{Protein}

Hidrolisat protein merupakan salah satu produk protein konsentrat dari hasil perikanan. Hasil analisis kadar protein hidrolisat protein ikan toman dengan enzim bromelain adalah sebesar $(40,74 \%)$. Hasil ini lebih tinggi dibandingkan kadar protein 
hidrolisat protein ikan nila $(30,17 \%)$, ikan bandeng $(27,98 \%)$ dan Ikan cucut $(28,27 \%)$ (Annisa et al., 2017)

(Rochima et al., 2015), menjelaskan bahwa tinggi atau rendahnya nilai protein yang terukur dapat dipengaruhi oleh besarnya kandungan air yang hilang (dehidrasi) dari bahan. Nilai protein yang terukur akan semakin besar jika jumlah air yang hilang semakin besar. Ikan toman segar memiliki kadar protein sebesar 18,92\% (Restu, 2012), sedangkan hasil analisa kadar protein daging ikan toman segar pada penelitian ini sebesar $21,32 \%$. Hal ini menunjukkan terjadi peningkatan kadar protein pada ikan toman setelah proses hidrolisis. (Purbasari, 2008) menjelaskan bahwa peningkatan kandungan protein dalam produk hidrolisat disebabkan selama proses hidrolisis terjadi konversi protein yang bersifat tidak larut menjadi senyawa nitrogen yang bersifat larut, selanjutnya terurai menjadi senyawa-senyawa yang lebih sederhana seperti peptida dan asam amino sehingga mudah diserap oleh tubuh.

Kenaikan nilai protein menunjukkan meningkatnya jumlah total nitrogen pada hidrolisat protein ikan toman karena metode analisis yang digunakan adalah metode Kjeldahl yang menggunakan jumlah nitrogen sebagai konversi pada perhitungan kadar protein.

\section{Lemak}

Menurut Shahidi et al., (1995) pada saat proses hidrolisis enzimatis terjadi perubahan struktur jaringan ikan yang sangat cepat sehingga menyebabkan kadar lemak menurun. Hasil pengamatan dengan mikroskop elektron terhadap bagian tipis dari otot ikan menunjukkan protein miofibril banyak berkurang selama proses hidrolisis, sedangkan sistem membran sel otot terlihat relatif resisten dari kerusakan. Pada saat proses hidrolisis, membran ini cenderung berkumpul dan membentuk gelembung yang tak larut, mengakibatkan hilangnya membran lipid yang berdampak pada penurunan kadar lemak.

Kadar lemak hidrolisat protein ikan toman dari enzim yang digunakan adalah 0,05\%. Rendahnya kadar lemak produk hidrolisat ikan toman ini disebabkan oleh adanya perubahan struktur jaringan ikan saat proses hidrolisis dan lemak biasanya dihilangkan bersama protein tidak larut dengan cara sentrifugasi. Adanya proses pemanasan menggunakan suhu dan tekanan tinggi pada tahap persiapan bahan baku dan proses pemisahan hidrolisat cair menggunakan penyaringan dan sentrifugasi berpengaruh pada kehilangan lemak. (Purbasari, 2008) menjelaskan bahwa penurunan kadar lemak pada produk HPI disebabkan pada saat proses hidrolisis enzimatis terjadi perubahan struktur jaringan ikan yang sangat cepat. Pengamatan dengan mikroskop elektron terhadap bagian tipis dari otot ikan memperlihatkan bahwa protein myofibril banyak berkurang selama proses hidrolisis, sedangkan system membran sel otot terlihat relatif resisten dari kerusakan. Pada saat proses hidrolisis, membran ini cenderung berkumpul dan hilangnya membran lipid. Kadar lemak di hidrolisat protein ikan sangat berkurang apabila dibandingkan dengan bahan baku karena lemak biasanya diangkat bersama fraksi protein tidak larut oleh pemisahan sentrifugasi (Molla \& Hovannisyan, 2011)

Kadar lemak hidrolisat protein ikan toman yang rendah ini, menghasilkan produk yang lebih stabil dan tahan lama. Selain itu, rendahnya kadar lemak pada produk hidrolisat dapat digunakan sebagai bahan makanan diet, yaitu makanan dengan kandungan lemak kurang dari $5 \%$ dan sebagai suplemen pada pembuatan roti tawar dan makanan bayi (Piggot \& Tucker, 1990).

\section{Profil Asam Amino}

Molekul protein tersusun dari sejumlah asam amino sebagai bahan dasar yang saling berikatan satu sama lain. Sebuah asam amino terdiri dari sebuah gugus amino $\left(\mathrm{NH}_{2}\right)$, sebuah gugus karboksil $(\mathrm{COOH})$, sebuah atom hidrogen dan gugus $\mathrm{R}$ (rantai cabang) yang terikat pada sebuah atom karbon (Winarno, 1998). Rantai asam amino 
yang dihubungkan dengan ikatan peptida akan membentuk protein dengan beragam struktur yang komplek dan khas. Reaksi hidrolisis protein bertujuan untuk mengubah protein menjadi bentuk yang lebih sederhana yaitu asam amino dan peptida melalui pemutusan ikatan peptida.

Hidrolisis secara enzimatis dapat menghasilkan penurunan ukuran peptida sehingga dapat mengubah karakteristik fungsional protein dan meningkatkan kualitasnya. Protein hidrolisat yang diperoleh setelah hidrolisis menghasilkan protein yang tersusun dari asam-asam amino bebas dan peptida rantai pendek yang memberikan keuntungan sebagai pangan fungsional karena profil asam aminonya. Protein hidrolisat yang diperoleh setelah hidrolisis menghasilkan protein yang tersusun dari asam-asam amino bebas dan peptida rantai pendek yang memberikan keuntungan sebagai pangan fungsional karena profil asam aminonya.

Komposisi asam amino pada berbagai protein pangan berperan dalam aktivitas fisiologi tubuh manusia dan secara langsung maupun tidak langsung berpengaruh terhadap kesehatan. Komposisi asam amino pada hidrolisat protein ikan berperan penting karena nilai nutrisi dan pengaruhnya terhadap sifat fungsional (dos Santos et al., 2011). Komposisi asam amino hidrolisat protein ikan toman disajikan pada Tabel 3.

Tabel 3. Komposisi asam amino hidrolisat protein ikan toman

\begin{tabular}{lc}
\hline \multicolumn{1}{c}{ Jenis Asam Amino } & $\begin{array}{c}\text { Hidrolisat Protein Ikan Toman } \\
(\% \mathrm{~b} / \mathrm{b})\end{array}$ \\
\hline L-Serin & 1,86 \\
L-Asam Glutamat & 6,63 \\
L-Fenilalanin & 1,69 \\
L-Isoleusin & 1,60 \\
L-Valin & 2,01 \\
L-Alanin & 3,25 \\
L-Arginin & 3,40 \\
Glisin & 4,40 \\
L-Lisin & 3,67 \\
L-Asam Aspartat & 4,01 \\
L-Leusin & 3,24 \\
L-Tirosin & 1,00 \\
L-Prolin & 2,68 \\
L-Threonin & 2,21 \\
L-Histidin & 1,04 \\
\hline
\end{tabular}

\section{KESIMPULAN}

Hidrolisat protein ikan toman dapat dihasilkan melalui hidrolisis menggunakan enzim bromelain. Waktu hidrolisis berpengaruh terhadap rendemen dan derajat hidrolisis hidrolisat protein ikan toman. Waktu optimum proses hidrolisis ikan toman dengan enzim bromelain adalah 4 jam. Hidrolisat protein ikan toman memiliki asam amino jenis serin, asam glutamate, fenialanin, isoleusin, valin, arginine, glisin, lisin, asam aspartate, leusin, tirosin, prolin, threonine dan histidine.

\section{UCAPAN TERIMA KASIH}

Penulis mengucapkan terima kasih kepada Balai Riset dan Standardisasi Industri Samarinda yang telah membiayai dan memfasilitasi penelitian ini. 


\section{DAFTAR PUSTAKA}

Annisa, S., Darmanto, Y. S., \& Amalia, U. (2017). PENGARUH PERBEDAAN SPESIES IKAN TERHADAP HIDROLISAT PROTEIN IKAN DENGAN PENAMBAHAN ENZIM PAPAIN (The Effect of Various Fish Species On Fish Protein Hydrolysate With The Addition of Papain Enzyme). SAINTEK PERIKANAN: Indonesian Journal of Fisheries Science and Technology, 13(1), 24. https://doi.org/10.14710/ijfst.13.1.24-30

Ansyari, P., \& Slamat. (2020). KALIMANTAN SELATAN [ Food Characteristics of Indonesian Snakehead in. 4(2), 27-33.

AOAC. (2005). Official Methods of Analysis. 16th ed. AOAC Int., Washington. D.C.

Belitz, Grosch, \& Schieberle. (2009). Food chemistry (4th ed.). German: Garching (Chapter 18).

Berk, Z. (2009). Food Proces Engineering and Technology. New York: Academic Press.

Chalamaiah, M., Dinesh, B., Hemalatha, R., \& Jyothirmayi, T. (2012). Fish protein hydrolysates: Proximate composition, amino acid composition , antioxidant activities and applications: A review. Food Chemistry, 135(4), 3020-3038. https://doi.org/10.1016/j.foodchem.2012.06.100

Dewi, A. K., \& Satibi, L. (2009). Kajian pengaruh temperatur pengeringan semprot (spray dryer) terhadap waktu pengeringan dan rendemen bubuk santan kelapa (coconut milk powder). Konversi, 4(0), 25-31.

DKP Prov. Kaltim. (2019). Data Potensi Perikanan. Dinas Kelautan dan Perikanan Propinsi Kalimantan Timur.

dos Santos, S. D. A., Martins, V. G., Salas-Mellado, M., \& Prentice, C. (2011). Evaluation of Functional Properties in Protein Hydrolysates from Bluewing Searobin (Prionotus punctatus) Obtained with Different Microbial Enzymes. Food and Bioprocess Technology, 4(8), 1399-1406. https://doi.org/10.1007/s11947-009-0301-0

Firlianty, F., \& Pratasik, S. B. (2018). Potensi Puding Ikan Toman (Channa Micropeltes) dan Ikan Gabus (Channa Striata) untuk Percepatan Penyembuhan pada Hewan Uji Tikus. Agrikan: Jurnal Agribisnis Perikanan, 11(2), 65. https://doi.org/10.29239/j.agrikan.11.2.65-69

Firlianty, F., Rario, R., Naibaho, E. B., \& Elita, E. (2019). Karakteristik Gel HPMC Ekstrak Ikan Toman (<em>Channa micropeltes</em>). Agrikan: Jurnal Agribisnis Perikanan, 12(1), 8. https://doi.org/10.29239/j.agrikan.12.1.8-12

Hariyadi, P. (2017). PENGERING SEMPROT: Aplikasinya untuk Mikroenkapsulasi Komponen Fungsional. Foodreview Indonesia, XII(5), 50-53.

Haslaniza, H., Maskat, M. Y., Wan Aida, W. M., \& Mamot, S. (2010). The effects of enzyme concentration, temperature and incubation time on nitrogen content and degree of hydrolysis of protein precipitate from cockle (Anadara granosa) meat wash water. International Food Research Journal, 1入1), 147-152.

He, S., Franco, C., \& Zhang, W. (2013). Functions , applications and production of protein hydrolysates from fi sh processing. FRIN, 50(1), 289-297. https://doi.org/10.1016/j.foodres.2012.10.031

Hermanto, H., \& Susanty, A. (2020). Karakteristik Fisikokimia dan Sensoris Biskuit dengan Penambahan Tepung Ikan Toman (Channa micropletes). Jurnal Riset Teknologi Industri, 14(2), 253. https://doi.org/10.26578/jrti.v14i2.6182

Jamil, N. H., Halim, N. R. A., \& Sarbon, N. M. (2016). Optimization of enzymatic hydrolysis condition and functional properties of eel (Monopterus sp.) protein using response surface methodology (RSM). International Food Research Journal, 23(1), 1-9.

Kembaren, R. B., Putriliniar, S., Maulana, N. N., Yulianto, K., Ikono, R., Rochman, N. T., \& Mardliyati, E. (2014). Ekstraksi Dan Karakterisasi Serbuk Nano Pigmen Dari Daun Tanaman Jati (Tectona Grandis Linn. F). Jurnal Kimia Dan Kemasan, 36(1), 313-318. https://doi.org/10.24817/jkk.v36i1.1904

KKP. (2021). KKP, 2021.docx.pdf. Https://Statistik.Kkp.Go.Id/ (diakses pada 19 Desember 
2021)

Lekha, D. (2020). Mengenal Lebih Dekat Ikan Toman. www.majalahikan.com (diakses pada 10 Juni 2021)

Maziyatul, M., Ita N, A., \& Takwanto, A. (2019). PENGARUH SUHU SPRAY DRYING DAN PENAMBAHAN MALTODEXTRIN TERHADAP AKTIVITAS ANTIOKSIDAN (IC50) PADA BAYAM HIJAU (AMARANTHUS HYBRIDUS L.). Distilat Jurnal Teknologi Separasi, 5(9), 52-57.

Misla Alfitri, Siti Aisyah, R. A. (2015). PENGARUH PENAMBAHAN DAGING IKAN TOMAN ( Channa micropeltes ) YANG PADA PENGOLAHAN SERUNDENG THE EFFECT OF ADDITION OF TOMAN FISH (Channa Micropeltes) WHICH IS SEVERAL TO ABU LEVELS, PROTEIN LEVELS AND FATIC LEVELS IN. 78-87.

Molla, A. E., \& Hovannisyan, H. G. (2011). International Aquatic Research Optimization of enzymatic hydrolysis of visceral waste proteins of beluga Huso huso using Protamex. International Aquatic Research, 3, 93-99. www.intelaquares.com

Nurilmala, M., Safithri, M., Pradita, F. T., \& Pertiwi, R. M. (2020). PROFIL PROTEIN IKAN GABUS ( Channa striata ), TOMAN ( Channa micropeltes ), DAN BETUTU ( Oxyeleotris marmorata ) Protein Profile of Striped Snakehead ( Channa striata), Giant Snakehead ( Channa micropeltes ), and Marble Goby ( Oxyeleotris marmorata ). Jphpi, 23, 548-557. http://journal.ipb.ac.id/index.php/jphpi/article/view/33924

Piggot, G. M., \& Tucker, B. W. (1990). Seafood:Effects of Technology on Nutrition. Marcel Dekker, Inc

Purbasari, D. (2008). Produksi dan Karakterisasi Hidrolisat Protein Dari Kerang Mas Ngur (Atactodea striata). In Skripsi Fakultas Perikanan dan IImu Kelautan Institut Pertanian Bogor.

Restu. (2012). Utilization of toman fish (Channa micropeltes) as nugget material. Jurnal IImu Hewani Tropika, 1(2), 67-70.

Rochima, E., Pratama, R., \& Djunaedi, O. (2015). Karakterisasi Kimiawi Dan Organoleptik Pempek Dengan Penambahan Tepung Tulang Ikan Mas Asal Waduk Cirata. Jurnal Akuatika Indonesia, 6(1), 245786.

Roslan, J., Yunos, K. F. M., Abdullah, N., \& Kamal, S. M. M. (2014). Characterization of Fish Protein Hydrolysate from Tilapia (Oreochromis Niloticus) by-Product. Agriculture and Agricultural Science Procedia, 2, 312-319. https://doi.org/10.1016/j.aaspro.2014.11.044

Salamah, E., Nurhayati, T., \& Widadi, I. R. (2012). PEMBUATAN DAN KARAKTERISASI HIDROLISAT PROTEIN DARI IKAN LELE DUMBO (Clarias gariepinus) MENGGUNAKAN ENZIM PAPAIN. Jurnal Pengolahan Hasil Perikanan Indonesia, 15(1). https://doi.org/10.17844/jphpi.v15i1.5328

Samaranayaka, A. G. P., \& Li-chan, E. C. Y. (2008). Food Chemistry Autolysis-assisted production of fish protein hydrolysates with antioxidant properties from Pacific hake ( $\begin{array}{llll}\text { Merluccius } \quad \text { productus 107, 768-776. } & \text {. }\end{array}$ https://doi.org/10.1016/j.foodchem.2007.08.076

Shahidi, F., Han, X. Q., \& Synowiecki, J. (1995). Production and characteristics of protein hydrolysates from capelin (Mallotus villosus). Food Chemistry, 53(3), 285-293. https://doi.org/10.1016/0308-8146(95)93934-J

Sulistyoningsih, M., Rakhmawati, R., \& Setyaningrum, A. (2019). KANDUNGAN KARBOHIDRAT DAN KADAR ABU PADA BERBAGAI OLAHAN LELE MUTIARA (Clarias gariepinus B). Jurnal IImiah Teknosains, 41. https://doi.org/10.26877/jitek.v5i1.3737

Wijayanti, I., Romadhon, R., \& Rianingsih, L. (2016). KARAKTERISTIK HIDROLISAT PROTEIN IKAN BANDENG (Chanos chanos Forsk) DENGAN KONSENTRASI ENZIM BROMELIN YANG BERBEDA Caracteristic of Milkfish (Chanos chanos Forsk) Protein Hydrolysate as effect of Different Bromelin Enzyme Concentration. SAINTEK 
PERIKANAN: Indonesian Journal of Fisheries Science and Technology, 11(2), 129. https://doi.org/10.14710/ijfst.11.2.129-133

Winarno, F. G. (1998). Kimia Pangan dan Gizi. Penerbit PT Gramedia Pustaka Utama, Jakarta. Penerbit PT Gramedia Pustaka Utama, Jakarta. 